\title{
PERMAINAN KATA BERANTAI "BELAJAR DARI COVID-19" SEBAGAI STRATEGI MODIFIKASI KONSELING MODEL KIPAS
}

\author{
Nisa Ariantini, Sopianto \\ Program Studi Bimbingan dan Konseling, Universitas Borneo Tarakan \\ Email: ariantiny.nisa@gmail.com
}

\begin{abstract}
Abstrak
Konseling Model KIPAS menawarkan beberapa strategi modifikasi yang mengadopsi teknik-teknik dari permainan tradisional yang ada disuatu wilayah. Teknik-teknik dapat yang dapat digunakan konselor dalam pelaksanaan layanan konseling di sekolah, salah satunya dengan mengkonstruksi salah satu permainan tradisional di wilayah Kalimantan Utara. Permainan tradisional yang diangkat dalam penelitian tersebut, yaitu permainan kata berantai. Aplikasi online menjadi salah satu alternatif konselor dalam pemberian layanan dimasa pandemi seperti sekarang ini. Belajar dari Covid 19 dipilih sebagai tema permainan, agar para siswa dapat mengambil makna dari kegiatan pelayanan bimbingan konseling melalui study from home yang diberikan konselor. Penelitian ini bertujuan untuk mendeskripsikan prosedur hasil konstruksi dari beberapa permainan tradisional kata berantai, mendeskripsikan prototype panduan permainan tradisional sebagai strategi Konseling Model KIPAS. Penelitian ini menggunakan tipe riset interaksionisme simbolik, karena peneliti ingin memahami makna interaksi dalam permainan kata berantai. Penelitian akan dilaksanakan oleh beberapa siswa SMA di Kota Tarakan dari sekolah yang berbeda-beda. Teknik analisis data dilakukan melalui describing data, categorization data, dan connecting data.
\end{abstract}

Kata Kunci : Permainan Kata Berantai, Konseling Model KIPAS

\section{PENDAHULUAN}

Akhir tahun 2019, dunia dikejutkan dengan wabah virus corona (Covid-19) yang menifeksi hamper seluruh Negara di dunia. WHO sejak Januari 2020 telah menyatakan dunia masuk ke dalam darurart global terkait viru corona (Iswari, Saragi, Sirait, \& Putra, 2020). Pandemi Covid-19 mempengaruhi hamper semuaaspek kehidupan, tak terkecuali aspek pendidikan (Anderson, 2020; Azzi-Huck \& Shmis, 2020). Untuk memutus mata rantai penyebaran Covid -19, dimana siswa dapat berperan sebagai pembawa atau penyebar penyakit tanpa gejala, hampir semua Negara meniadakan kegiatan di sekolah.

Di Indonesia, pemerintah telah mengeluarkan status darurat bencana terhitung mulai 29 Februari 2020 hingga 29 Mei 2020 terkait pandemic virus corona dengan jumlah waktu 91 hari (Koesnawardhani, 2020). Langkah yang telah dilakukan pemerintah untuk mengurangi penyebaran virus Covid19, salah satunya dengan mensosialisasikan gerakan Social Distancing dan PSBB (Pembatasan Sosial Berskala Besar). 
Pada tanggal 24 Maret 2020 Menteri Pendidikan dan Kebudayaan Republik Indonesia mengeluarkan Surat Edaran Nomor 4 Tahun 2020 tentang Pelaksanaan Kebijakan Pendidikan dalam Masa Darurat Penyebaran COVID-19, dala Surat Edaran tersebut dijelaskan bahwa proses belajar dilaksanakan di rumah melalui pembelajaran daring/jarak jauh dilaksanakan untuk memberikan pengalaman belajar bermakna bagi siswa. Kegiatan Belajar Mengajar (KBM) dipindahakan di rumah, tetapi masih harus dikendalikan oleh guru atau dosen dan orang tua dengan menggunakan pembelajaran jarak jauh (Zaharah, Kirilova, \& Windarti, 2020).

Pembelajaran daring merupakan sebuah pembelajarann yang dilakukan dalam jarak jauh melalui media berupa internet dan alat penunjang lainnya, seperti telepon seluler atau computer. Pembelajaran daring sangat berbeda dengan pembelajaran seperti biasa, menurut Riyana (2019) pembelajaran daring lebi menekankan pada ketelitian dan kejelian peserta didik dalam menerima dan mengelola informasi yang disajikan secara online. Konsep pembelajaran daring memiliki konsep yang sama dengan e-learning.

Kegiatan pembelajaran secara daring ini pada dasarnya sangat beragam, antara lain dapat dilaksanakan melalui google classroom, zoom, tv edukasi, belajar interaktif diportal rumah belajar, ruang guru, dan aplikasi belajar online lainnya yang telah direkomendasi oleh Kemdndibud maupun melalui media social, seperti aplikasi whatsapp (Sedyawati, 2020). Selama berlangsungnya kegiatan belajar di rumah (BDR) yang diberlakukan oleh pemerintah membuat siswa mencari cara baru, gaya belajar baru, kebiasaa belajar yang dimodifikasi sedimikan rupa sehingga mampu beradaptasi kembali dengan keadaan belajar dari rumah. Slameto (dalam Siagan, 2015) menjelaskan bahwa kebiasaan belajar akan mempengaruhi belajar itu sendiri, yang bertujuan untuk mendapatkan pengetahuan, sikap kecakapan dan keterampilan dalam belajar.

Pembelajaran daring yang diintruksikan oleh pemerintah juga ditetapkan dalam pemberian layanan bimbingan dan konseling. Penerapan layanan bimbingan dan konseling daring melalui internet memerlukan sejumlah media yang dapat disesuaikan dengan sifat bimbingan. Ketersediaan peralatan dan penguasaan teknologi sangat diperlukan oleh semua pihak, baik guru kelas maupun konselor sekolah. (Satriah, Miharja, Setiana, \&Rohim, 2020). Arsyad (dalam Sukiyasa \&Sukoco, 2013) mengungkapkan bahwa media pembelajaran dapat meningatkan dan mengarahkan perhatiansiswa sehingga dapat menumbuhkan motivasi belajar, interaksi lebih langsung antara siswa dengan lingkungannya, serta siswa belajar sendiri sesuai minat dan kemampuannya.

Salah satu media pembelajaran yang efektif untuk meningkatkan kemampuan kognitif, afektif, da psikomotorik siswa dalam proses belajar mengajar adalah dengan menggunakan permainan tradisional. Permainan tradisional merupakan permainan yang telah diturunkan dari satu generasi ke generasi berikutnya dimana permainan tersebut mengandung nilaibaik, positif, bernilai, dan diinginkan (Bishop \& Curtis, 2005). Pada dasarnya dengan permainan memiliki fungsi dalam aspek 
fisik, motoric, emosi, kepribadian, serta memiliki fungsi juga dalam perkembangan social, kognitif ketajaman pengindraan dan mengasah keterampilan (Tedjasaputra, dalam Siwnarti, 2010).

Pelayanan BK pada satuan pendidikan adalah pelayanan bantuan profesional untuk peserta didik, baik secara perorangan maupun kelompok, agar peserta didik mampu mandiri dan mengendalikan diri serta berkembang secara optimal dalam bidang pengembangan kehidupan pribadi, kehidupan sosial, kemampuan belajar, dan perencanaan karir, melalui berbagai jenis layanan dan kegiatan pendukung. Layanan Klasikal termasuk komponen pelayanan dasar yang cenderung bersifat preventif disusun secara terstruktur untuk mencapai tujuan layanan. Mengingat pentingnya layanan klasikal sebagai salah satu bentuk layanan yang akan membimbing peserta didik berkembang seperti yang disampaikan di atas maka layanan format ini perlu disajikan sebaikbaiknya dengan melibatkan peran serta siswa dalam proses interaksi.

Oleh karena itu, dalam situasi pandemic saat ini konselor perlu menggunakan berbagai inovasi agar tetap memberikan pelayanan secara optimal kepada siswa. Perlu adanya inovasi dan kreativitas guru BK untuk mencari teknik-teknik menarik yang dapat digunakan sebagai strategi modifikasi dalam Konseling Model KIPAS. Konseling Model KIPAS menawarkan beberapa strategi modifikasi yang mengadopsi teknikteknik dari permainan tradisional yang ada disuatu wilayah. Teknik yang dapat yang dapat digunakan guru BK dalam pelaksanaan layanan konseling di sekolah, salah satunya dengan mengkonstruksi salah satu permainan tradisional.

Pada umumnya permainan tradisional selalu dikemas dalam lingkup tata muka, tetap dalam kondisi pandemic seperti ini konselor bisa menggunakan salah satu permainan tradisional yang bisa dilaksanakan via daring, yaitu kata berantai. Kata berantai merupakan salah satu contoh permaian bahasa. Menurut Sugiarsih (2010) permainan bahasa merupakan permainan untuk memperoleh kesenangan dan untuk melatih keterampilan berbahasa (menyimak, menulis, mendengar, dan membaca). Teknik kata berantai merupakan metode yang dilaksanakan dengan cara memberikan pesan kemudian siswa tersebut memberikan pesan tersebut kepada temannya (Gusrizal, 2000).

Kata berantai tidak hanya berungsi sebagai permainan untuk mengisi waktu luang, akan tetapi kata berantai juga memiliki beberapa manfaat, yaitu: 1) Membangkitkan minat belajar siswa, 2) Melatih kemampuan menyimak dan berbicara siswa, 3) Variasi dalam proses pembelajaran supaya siswa tidak bosan, dan 4) Siswa dapat belajar sambil bermain (Suyanto, dalam Aryati, 2014). Tujuan penelitian ini, yaitu untuk mengetahui prosedur-prosedur dalam permainan kata berantai "Belajar dari Covid-19" dan untuk mengetahui protype panduan permainan kata berantai "Belajardari Covid-19" sebagai Strategi Modifikasi Konseling Model KIPAS.

\section{METODE PENELITIAN}

Penelitian ini menggunakan metode kualitatif untuk mengungkap gejala secara holistik-kontekstual melalui pengumpulan data dari latar alami dengan memanfaatkan diri 
peneliti sebagai instrumen kunci. Penelitian ini menggunakan rancangan tipe interaksionisme simbolik, yaitu peneliti memaknai interaksi antar inidividu dan simbol-simbol yang nampak seperti; bahasa; ritme-ucap; penekanan kata; postur; gestur; mimik dari interaksi yang terjadi dipermainan serta makna yang individu berikan terhadap itu semua.

Penelitian ini menggunakan teknik pengambilan sampel secara purposive. Subjek dalam penelitian ini adalah siswa-siswa kelas VII, dan VIII dari SMP Negeri 2 Tana Tidung sebanyak 8 orang dan siswa SMP Negeri 1 Tanjung Palas sebanyak 8 orang. Terpilihnya subjek penelitian didasarkan kriteria, antara lain: 1) subjek pernah memainkan permainan tangkap lokam sebelumnya, 2) subjek dapat diajak bekerjasamaa untuk melakukan permainan, 3) subjek dapat dijadikan informan dalam penelitian, serta 4) subjek dapat menjalin hubungan akrab dengan peneliti.

Kehadiran dan keterlibatan peneliti di lapangan adalah untuk menemukan makna dan tafsiran dari subjek yang tidak bisa digantikan dengan alat lain (non human) dalam hal ini peneliti memanfaatkan dirinya sebagai instrumen utama. Adapun teknik analisis data dalam penelitian ini menggunakan beberapa strategi, diantaranya describing data, categorization data, dan connecting data.

\section{HASIL DAN PEMBAHASAN}

Berdasarkan hasil observasi yang telah dilakukan oleh surveyor, telah ditentukan sebanyak 9 orang siswa yang dipilih dari beberapa SMA di Kota Tarakan diantaranya SMA Hang Tuah, SMA Muhammadiyah, dan SMA
Negeri 2 Tarakan. Peserta dipilih karena dianggap pernah memainkan permainan ini sebelumnya, dan memiliki keterikatan dengan surveyor agar mudah menjalin komunikasi karena pelaksanaan penelitian yang dilakukan saat siswa menjalani study from home. Surveyor melakukan komunikasi melalui whatsapp Group yang dibuatnya, untuk mendata kelengkapan agar peneliti segera menjalankan penelitiannya.

Penelitian di laksanakan pada Sabtu, 9 Oktober 2020 melalui aplikasi Google Meet melalui link (https://meet.google.com/akz-axzs-

$q \boldsymbol{p} \boldsymbol{w})$. Penelitian dibuka oleh peneliti, dengan melakukan perkenalan awal bersama dengan para peserta penelitian. Peneliti memberikan penjelasan singkat mengenai tujuan dilaksanakan penelitian, dan rancangan kegiatannya. Kemudian, peneliti menanyakan kepada peserta atas kesediaannya menjadi anggota kelompok, tetapi peserta menyerahkan secara penuh jalannya kegiatan agar dipandu oleh peneliti.

Tidak seperti permainan pada umumnya, yang selalu diawali dengan pembagian kelompok. Kali ini itu tidak dilakukan, karena permainan ini akan tetap bisa dijalankan walaupun jumlah peserta yang bermain banyak dan hanya memerlukan satu kelompok saja. Sebelum terlaksananya penelitian ini, peneliti sebelumnya telah menyiapkan beberapa sub tema yang sesuai dengan tema utamanya "Belajar dari Covid19". Ada sekitar 5 sub tema yang telah disiapkan oleh peneliti, dan akan ditayangkan melalui screen share pada layar meet.

Permainan dimulai dengan bernyanyi bersama sambil peneliti menyebutkan tema dan siapa yang akan memulai menyebutkan katanya sambil 
bertepuk tangan bersama. Tema Pertama, "Mulaaaaaiiiiiii... Sebutkan bagaimana kondisi kalian belajar di rumah? Dimulai dari Widyah", "Membosankan" kata Widyah, "Jenuh" kata Sofiyah, "Banyak PR" kata Afiqah, "Susah" kata Nilam, "Gak asik" kata Musdalifah, "Pusing" kata Rindi, "cepat ngantuk" kata Shinta, dan "Diganggu ade" kata Sri. Setelah menyebutkan kata atau kalimat yang cocok untuk menggambarkan sub tema sesuai dengan yang mereka alami, peneliti menanykan kesetiap peserta penelitian "bagaimana kondisi tersebut bisa dialami oleh peserta?". Sebagian besar peserta mengharapkan bisa segera kembali beajar seperti biasa di sekolah, karena banyaknya tugas yang diberikan, dan kurangnya guru memberikan penjelasan sehingga peserta penelitian mengalami kejenuhan beajar di rumah. Selain itu, peserta merasa tidak focus jika mengerjakan banyak tugas di rumah, karena disisi lain mereka harus sambil membantu ibunya mengerjakan pekerjaan rumah, seperti menjaga adik, mencuci piring, dll.

Tema

Kedua,

"Mulaaaaiiiiii. Sebutkan nama-nama penyakit berbahaya? Dimulai dari Sofiyah". "Kanker" kata Sofiyah, "Diabetes" kata Afiyah, "Jantung" kata Widyah, "Stroke" kata Nilam, "Corona" kata Musdalifah, "Sesak Nafas" kata Rindi, dan "Tekanan" kata Sri. Selanjutnya, peneliti menanyakan "Kenapa penyakit tersebut dapat menjadi berbahaya?", seluruh peserta pun kompak menjawabkan bahwa penyakit-penyakit tesebut dapat mengakibatkan kematian.

Tema Ketiga, "Mulaaaaaaiiiiii. Sebutkan apa saja yang menyebabkan covide-19 berbahaya?" Dimulai dari Afiqah. "Mematikan" kata Afiqah, "Jauh dari keluarga" kata Afiqah,
"Terisolasi" kata Sofiyah, "Menurunkan imun" kata Musdalifah, "Membuat sesak nafas" kata Shinta, "Kematian" kata Rindi, "Fisik menjadi lemah" kata Sri, dan "Belum ada vaksinnya" kata Nilam.

Tema Keempat, "Mulaaaaiiiii... Sebutkan hidup sehat apa saja yang sudah kalian lakukan agar terhindar dari covid19? Dimulai dari Sri". "Cuci Tangan" kata Sri, "Olahraga" kata Sofyah, "Menjaga jarak" Widyah, "Memakai masker" kata Nilam, "Tidak berkerumun" Kata Musdalifah, dan "Makan makanan yang sehat" kata Rindi.

Tema Kelima, "Mulaaaaaiiiiii... Sebutkan bagaimana saja caranya agar terhindar dari Covid-19?". Pada tema ini peneliti meminta peserta untuk memberikan penjelasan dari pertanyaan yang disampaikan, "Mengurangi aktivitas diluar rumah, jika itu nda terlalu penting" ucap Afiqah. "Mengkonsumsi vitamin penambah imun daya tubuh, kayak UC 1000mg, Vitacimin, Xonci, dll" Kata Nilam.

Berdasarkan hasil kegiatan penelitian tersebut, prosedur penelitian bermain kata tidak memerlukan minimum peserta untuk bisa mengikuti permainan tersebut. Karena semakin banyak peserta, akan semakin banyak kata yang disebutkan sehingga akan menambah informasi bagi para peserta lainnya. Dalam kegiatan outdoor atau secara langsung, peserta hanya diminta duduk melingkar sambil berpegangan tangan dan melakukan tepuk tangan seirama saat ketua menyampaikan kata apa yang disebutkan, dan saat temannya menyebutkan jawaban dari pertanyaan. Biasanya bagi peserta yang tidak bisa menyebutkan kata lain dari yang sudah disebutkan oleh temannya, maka peserta akan keluar dari lingkaran dan 
siap mendapatkan hukuman jika sudah ditemukan pemenang permainan.

Siswa berhak mendapatkan pelayanan konseling yang menggembirakan mengenai dirinya, dalam pelaksanaan konseling. Model konseling KIPAS mengorientasikan bersifat "happy electism" dalam pelaksanaannya di sekolah. Model KIPAS merencanakan tindakan konseling dalam beberapa strategi modifikasi, salah satunya adalah pemberdayaan (empowering) dengan menggunakan permainan kata berantai

Permainan kata berantai dapat digunakan oleh guru BK sebagai salah satu teknik bimbingan konseling dalam pelaksanaan layanan konseling. Tetapi hal tersebut masih belum banyak dilakukan oleh guru BK disekolah, melalui pemberian teknik layanan yang khas, dan unik baik dalam pelaksanaan konseling didalam ataupun diluar kelas, akan membantu guru BK dalam mengembangkan diri siswa.

Rusmana (2009) menjelaskan bahwa teknik permainan dalam pelayanan bimbingan dan konseling sebagai sebuah wahana dalam pemecahan masalah melalui peragaan, dengan langkah-langkah identifikasi masalah, analisis dan hasil diskusi. Dimana melalui permainan mampu menumbuhkan empati dan memudahkan dalam penyesuian diri dengan kondisi yang ada karena fungsi dari permainan adalah mengeluarkan masalah dalam diri seseorang.

Pelaksanaan konseling dapat membantu seseorang memahami dirinya, mencegah masalah, mampu memperbaiki diri, serta menjalankan perkembangan secara optimal melalui informasi serta pengalaman lewat aktivitas kelompok. Dalam hal ini, permainan pan fabat dan gumbak karit sinan dapat digunakan sebagai salah satu teknik sebagai strategi konseling model KIPAS untuk meningkatkan perkembangan bidang bimbingan dan konseling siswa (Gibson, 2011)

\section{KESIMPULAN}

Konseling karier model KIPAS hakikatnya merupakan suatu kerangka kerja yang dirancang dan disusun agar dapat beradaptasi dengan konteks lingkungan sosial-budaya (struktur dan pranata) sekolah dan keadaan psikologis siswa di Indonesia. Strategi/teknik khusus yang digunakan mengacu pada sistem nilai budaya Tarakan. Implementasinya tidak terbatas pada tiga budaya tersebut, namun dapat diterapkan di seluruh Indonesia dengan menyesuaikan keragaman dan keunikan budaya siswa/konseli. Hal yang perlu dicermati untuk selanjutnya ialah berupaya mengkaji secara mendalam serta terarah sistem nilai yang terkandung dalam setiap budaya baik falsafah budaya, pepatah, pengharapan, permainan rakyat, pantun, dan lain-lain sebagai suatu teknik konseling berbasis budaya nusantara.

Berdasarkan hasil kegiatan penelitian tersebut, prosedur penelitian bermain kata tidak memerlukan minimum peserta untuk bisa mengikuti permainan tersebut. Karena semakin banyak peserta, akan semakin banyak kata yang disebutkan sehingga akan menambah informasi bagi para peserta lainnya. Dalam kegiatan outdoor atau secara langsung, peserta hanya diminta duduk melingkar sambil berpegangan tangan dan melakukan tepuk tangan seirama saat ketua menyampaikan kata apa yang disebutkan, dan saat temannya menyebutkan jawaban dari pertanyaan. Biasanya bagi peserta yang tidak bisa 
menyebutkan kata lain dari yang sudah disebutkan oleh temannya, maka peserta akan keluar dari lingkaran dan siap mendapatkan hukuman jika sudah ditemukan pemenang permainan.

\section{REFERENSI}

Anderson, J. (2020, March). Should schools close when coronavirus cases are still rare? Quartz.

Aryati, Rizqi Khaerani. 2014. Efektifitas Permainan Kata Berantai Untuk Meningkatkan Kemampuan Berbicara Siswa SMA Negeri 1 Tegal : Universitas Negeri Semarang.

Bishop, J.C. \& Curtis, M. (2005). Permainan anak-anak zaman sekarang. Editor: Yovita Hadiwati. Jakarta: PT. Grasindo.

Gibson, Rl \& Mitchell. 2011. Bimbingan dan Konseling. Yogyakarta: Pustaka Pelajar.

Gusrizal. 2000. Mari Belajar Bahasa Indonesia. Jakarta: Akademika Pressindo

Iswinarti. (2010). Nilai-nilai terapiutik permainan tradisional engklek untuk anak usia sekolah dasar. Naskah Publikasi. Penelitian Dasar Keilmuwan. Fakultas Psikologi. Malang: Universitas Muhammadiyah Malang.

Koesmawardhani, N. W. (2020). Pemerintah Tetapkan Masa Darurat Bencana Corona hingga 29 Mei 2020. Detiknews. Diunduh Dari Https://news. Detik. Com/berita/d4942327/pemerint ah-Tetapkan-MasaDaruratBencana-Corona-Hingga-29Mei-2020.
Riyana, C. (2019). Produksi Bahan Pembelajaran Berbasis Online. Universitas Terbuka.

Rusmana, N. 2009. Bimbingan dan Konseling kelompok di Sekolah (Metode, Teknik, dan Aplikasi). Bandung: Rizqi Press.

Satriah, L., Miharja, S., Setiana, W., \& Rohim, A. S. (2020). Optimalisasi bimbingan online dalam upaya mencegah penyebaran virus Covid-19 pada Fakultas Dakwah dan Komunikasi, UIN SGD Bandung.

Sedyawati, E. (2020). Candi indonesia/Penulis, Edi Sedyawati [and eight others]; fotografer, Feri Latief [and six others].

Siagian, R.E.F. 2015. Pengaruh Minat dan Kebiasaan Belajar Siswa terhadap Prestasi Belajar matematika. Jurnal Formatif, 02 (02): 122.131.

Sugiarsih, Septia. 2010. Permainan Bahasa dalam Pembelajaran Bahasa Indonesia di Sekolah Dasar. $\quad$ http://staff.uny.ac.id. diakses 6 April 2015.

Sukiyasa, K., \& Sukoco. (2013). Pengaruh media animasi terhada hasil belajar dan motivasi belajar siswa materi sistem kelistrikan otomotif. Jurnal Pendidikan Vokasi, 3, (1).

Zaharah, Z., Kirilova, G. I., \& Windarti, A. (2020). Impact of Corona Virus Outbreak Towards Teaching and Learning Activities in Indonesia. SALAM: Jurnal Sosial Dan Budaya Syar-I, 7(3), 269-282. 